\title{
Strategic marketing and business performance: A study in three European 'engineering countries'
}

\author{
Matti Jaakkola* \\ Researcher \\ Aalto University School of Economics \\ Department of Marketing and \\ Management \\ P.O. Box 21230 \\ FI-00076 Aalto \\ Helsinki, Finland \\ Tel. +358403538300 \\ Fax: +358943138660 \\ E-mail: matti.jaakkola@hse.fi \\ Petri Parvinen \\ Professor \\ Aalto University School of Economics \\ Department of Marketing and \\ Management \\ P.O. Box 21230 \\ FI-00076 Aalto \\ Helsinki, Finland \\ Tel. +358 505264661 \\ Fax: +358943138660 \\ E-mail: petri.parvinen@hse.fi
}

\author{
Kristian Möller \\ Professor \\ Aalto University School of Economics \\ Department of Marketing and \\ Management \\ P.O. Box 21230 \\ FI-00076 Aalto \\ Helsinki, Finland \\ Tel. +35850 3836190 \\ Fax: +358943138660 \\ E-mail: kristian.moller@hse.fi \\ Heiner Evanschitzky \\ Professor \\ University of Strathclyde \\ Department of Marketing \\ Stenhouse Building \\ 173 Cathedral Street \\ Glasgow G4 0RQ, UK \\ Tel. +44 1415485802 \\ Email: evanschitzky@strath.ac.uk
}

Hans Mühlbacher

Professor

University of Innsbruck School of Management

Department of Strategic Management, Marketing and Tourism

Universitaetsstr. 15

6020 Innsbruck, Austria

Tel. +43512507 7201

Fax: +43 5125072842

Email: hans.muehlbacher@uibk.ac.at

* Corresponding author and main contact person 


\section{Brief biographical sketches}

Matti Jaakkola is a researcher and doctoral candidate in marketing at the Aalto University School of Economics (formerly Helsinki School of Economics), Finland. His current research interests include market orientation and other strategic orientations, organizational capabilities, and business performance implications of the resource-based view of the firm.

Kristian Möller is a Research Professor and Director of the Business Networks Domain at the Aalto University School of Economics, Finland. He chairs the executive board of the Finnish Doctoral Program in Business Studies. Formerly the President of the European Marketing Academy and the Head of the Marketing and Management Department of the HSE, Dr. Möller is an active member of the international research network. He has been a visiting research scholar at Penn State, Aston Business School, University of Bath, and the European Institute for Advanced Studies in Management in Brussels. His current research is focused on business and innovation networks, competence-based marketing, and marketing theory. His work has been published in California Management Review, European Journal of Marketing, Industrial Marketing Management, International Journal of Research in Marketing, Journal of Business Research, Journal of Management Studies, Journal of Marketing Management, and Marketing Theory.

Petri Parvinen works as the Professor of Sales Management at the Aalto University School of Economics, Finland. He has worked with over 150 organizations, reinforcing commercial and business thinking particularly in environments where it does not spawn naturally. His research concentrates on explaining the dynamics of growth and profitability at the business unit level. Related work has previously appeared in e.g. Journal of Management Studies, Industrial Marketing Management, and Journal of Business and Industrial Marketing.

Heiner Evanschitzky is Professor of Marketing at the University of Strathclyde, UK. He received his $\mathrm{PhD}$ from the University of Muenster, Germany, and worked there as Assistant and Associate Professor. He was visiting scholar at Florida Atlantic University, USA. His research revolves around service-profit-chain issues and his particular interests include service marketing, retailing, marketing metrics, relationship marketing, and research methods. His work has been published in leading journals such as Journal of Marketing, Journal of Retailing, Journal of Service Research, Industrial Marketing Management, Journal of Personal Selling and Sales Management, and Journal of Business Research.

Hans Mühlbacher is Professor of business administration and Head of the Department of Strategic Management, Marketing and Tourism of the University of Innsbruck School of Management, Innsbruck, Austria. His current research interests are in the fields of virtual customer integration in new product development as well as multi-cultural branding. His publications appeared in journals such as Journal of Management Information Systems, International Journal of Research in Marketing, Journal of Business Research, European Journal of Marketing, or Industrial Marketing Management. 


\begin{abstract}
In spite of its relevance, the effects of strategic marketing on business performance are sparingly studied, especially in particular business contexts. We address this gap in two ways. First, we examine the influence of four key strategic marketing concepts - market orientation, innovation orientation, and two marketing capability categories (outside-in and inside-out capabilities) — on company performance. Second, these relationships are studied in three European "engineering countries:" Austria, Finland and Germany. Their relative homogeneity enables testing the generality versus context-specificity of strategic marketing's performance impact. Using SEM analysis, surprisingly weak relationships between market orientation and outside-in capabilities, and business performance are identified, as opposed to the strong role of inside-out capabilities and innovation orientation. These results can be understood through the "engineering country" characteristics. Moreover, clear differences in results are identified among these relatively homogenous countries. This is a major finding as it challenges the widely assumed generality of the strategic marketing-performance relationship. Country-specific results have also considerable managerial relevance.
\end{abstract}

\title{
Key words
}

Strategic marketing; business performance; resource-based view; business orientations; structural equation modeling 


\section{INTRODUCTION}

Marketing efforts and know-how are instrumental in commercializing ideas and inventions and in running successful business. Nevertheless, the effect of strategic marketing on business performance remains elusive, even despite an established research tradition (Srivastava, Shervani \& Fahey 1998; Matsuno, Mentzer \& Özomer 2002; Hooley, Greenley, Cadogan \& Fahy 2005). This may be due to the fact that the outcomes of strategic marketing are subject to many internal and external influences, making the identification of cause-and-effect linkages very hard (Bonoma \& Clark 1988). A related issue is that the majority of studies examine only the effects of two or three marketing factors at a time. This is a clear limitation compared to corporate reality. The current situation is alarming and several studies emphasize the urgency to demonstrate relationships between marketing inputs, processes and business outcomes (e.g. O’Sullivan \& Abela 2007; Morgan, Clark \& Gooner 2002).

Another critical aspect in the strategic marketing research is the dominance of crosssectional research design. By studying the marketing effects over several industries and even over countries, we receive highly averaged results that may also contain a lot of 'noise.' This methodological approach regards the influence of strategic marketing as generic. That is, the impact of marketing factors is presumed to be constant across different types of business contexts. This is a strong assumption and we lack sufficient knowledge of the effects of strategic marketing factors in particular business contexts (Morgan et al. 2002; Homburg, Workman \& Krohmer 1999; Makino, Isobe \& Chan 2004). This is an evident shortcoming, as research in market orientation suggests the 
relevance of contextual analysis, where even a cross-national meta-analysis of its performance impact is available (Ellis 2006). Additional evidence of contextuality is available through studies that employ the strategy typology of Miles and Snow (1978) as contextual determinants (e.g. Slater, Olson \& Hult 2006; Desarbo, Di Benedetto, Song \& Sinha 2005).

The present study addresses recognized research gaps in two ways. First, as recommended by Hooley, Greenley, Fahy \& Cadogan (2001), we examine the influence of four key strategic marketing concepts—market orientation (e.g. Narver \& Slater 1990; Kohli \& Jaworski 1990), innovation orientation (e.g. Siguaw, Simpson \& Enz 2006), and the two marketing capability categories (outside-in and inside-out capabilities; Day 1994) — on company performance. As company performance is a complex phenomenon, we model it using competitive advantage, market performance, and financial performance (e.g. Morgan et al. 2002). These solutions aim to match the complexity of strategic marketing and performance relationships.

Second, in order to examine the marketing-performance connection in a specific environment, we select countries as the research context and carry out analysis in Austria, Finland and Germany. These countries, coined "engineering countries," are chosen for a number of reasons. First, it will be shown that they are significantly similar in their business cultural heritages and business policies, all emphasizing technological and engineering innovations and having strong exports in these fields. These characteristics are interesting when examining the relative role of market orientation and marketing 
capabilities versus innovation orientation. Moreover, these three relatively homogenous countries provide a critical setting for testing the generality versus context specificity of the performance impact of strategic marketing. Finally, country-specific results also have considerable managerial relevance. To provide readers with a better understanding of this research strategy, the selected countries are briefly described next.

The general similarities among Austria, Finland and Germany, as "engineering countries," can be identified from extant research literature, as well as from our data. For example, for years, these countries' expenditures on research and development as a percentage of GDP are well above OECD and European Union averages (OECD 2008). To generalize, companies that operate in "engineering countries" tend to strive for product superiority, potentially at the expense of focusing on customer satisfaction and needs fulfillment. Moreover, companies in these countries have, relatively speaking, based significant amounts of their competitive strategies on high technology and process technology applications. Thus, we expect that engineering-oriented companies may gain success almost purely on the basis of engineering skills and process efficiencies, whereas their marketing abilities may be underdeveloped. Using the concepts of this study, "engineering countries" are inherently assumed to be more innovation-oriented than market-oriented, and possess more inside-out capabilities than outside-in capabilities. Accordingly, as argued by Avlonitis and Gounaris (1997), we would expect improvements in business performance if these companies are able to combine their engineering skills with enhanced marketing skills and market knowledge. These 
somewhat speculative expectations offer additional relevance when focusing on “engineering countries."

Austria currently boasts one of the fastest-growing engineering industries in Europe, while, in absolute numbers, Germany remains by far the largest producer of engineering equipment in the EU (Ayala, Spiechowicz \& Vidaller 2006). Despite Germany's strength in engineering-related industries (Randlesome 1994), German companies characteristically have lower levels of marketing professionalism than many of their international competitors (Shaw, Shaw \& Enke 2003). Likewise in Finland, engineering — and not marketing — is considerably important, as evidenced by its second position in a 2006 R\&D expenditures per GDP comparison among OECD countries (OECD 2008). In Finland and Austria, innovative activities and science-industry relations are approximately equal (Dachs, Ebersberger \& Pyka 2004), while Czarnitzki, Ebersberger and Fier (2007) argue that Finland and Germany have several comparables with regard to national innovation and $R \& D$ policies as well as public funding. Further, networking and close cooperation between universities and industry are seen as key strengths in both countries (Czarnitzki et al. 2007). These three countries have additional traits in common: high, closely similar standards of living (GDP per capita somewhat above the average of OECD countries) and easy access to European markets as members of the European Union.

To summarize, the primary objective of the present study is to empirically examine how market orientation, innovation orientation, and marketing capabilities affect the financial 
performance of companies through competitive advantages and market performance. Importantly, we consider country-specific moderation on performance, which almost all prior studies neglect (Ellis 2006 provides a notable exception). Accordingly, the questions we attempt to answer are:

1. How does strategic marketing, in terms of orientations and capabilities, influence company financial performance in "engineering countries?"

2. Are the results consistent within the "engineering countries," or are there any significant country-specific differences?

These questions are highly relevant for both theory development and managerial practice. Answer to the first provides a comprehensive model of the strategic marketingperformance relationship and the second question is critical to the assumption of the generic nature of this relationship. In more managerial terms, we examine whether it is innovation-driving company culture and principles, highly developed market orientation, or perhaps certain marketing capabilities that most strongly drive superior performance in the context of "engineering countries." Moreover, what are potential areas of improvement, and are these the same in all countries? Answers to these questions are of interest to any company that seeks profitable growth. If results suggest that the same rules clearly do not apply from one country to another, this can be a strong argument for the relevance of the "act local" principle also to strategic marketing.

The rest of the paper is structured as follows. The next section discusses the study's theoretical grounds and develops its general conceptual framework. This framework is 
then broken down into constructs and a set of hypotheses are constructed based on extant literature. Thereafter, the methodology, analysis and key findings are presented.

Discussion of both theoretical and managerial implications, limitations and avenues for further studies concludes the paper.

\section{THEORETICAL BACKGROUND}

In 1992, Webster suggests that the distinction between marketing and strategic planning is blurred, and the performers of these functions are increasingly the same. As such movement is evidenced, strategic marketing becomes a recognized phenomenon (see e.g. Fahy \& Smithee 1999). However, the concept of strategic marketing is used in various ways while an established definition is not yet available. In this paper, strategic marketing is defined as a deeply stakeholder-oriented concept that focuses on a company's long-term vision for competitive advantage and value-addition through innovation. This definition has its grounds on AMA's current (2007) definition of marketing (see below), but extends it by including innovation as a central marketingrelated, strategic business element.

"Marketing is the activity, set of institutions, and processes for creating, communicating, delivering, and exchanging offerings that have value for customers, clients, partners, and society at large.” (American Marketing Association 2007)

The present study finds theoretical grounds in the resource-based view (RBV) of the firm, according to which competitive advantage — and subsequently performance — depends on 
historically developed resource endowments (Wernerfelt 1984). Therefore, firms—and marketing in particular (Hooley et al. 2001)—should build on resources that contribute to their ability to produce valuable, rare, imperfectly imitable and non-substitutable market offerings in a manner that is either efficient or effective (Barney 1991; Hunt \& Morgan 1995). As Fahy and Smithee (1999) argue, intangible resources and capabilities, such as organizational learning (e.g. Santos-Vijande et al. 2005) and customer knowledge (e.g. Webster 1992) are especially difficult to duplicate and thus, provide a meaningful basis for marketing strategy and market position development. As such, intangible resources and capabilities have the potential to become distinctive competencies for the firm (Blois \& Ramirez 2006). In this sense, the present study also elaborates on the discourse surrounding competence-based marketing, which extends the focus from resources and competencies as inputs to resources and competencies also as marketable outputs (Zerbini et al. 2007).

Growing evidence in practice and academic research supports the idea that firm competencies and resources are key factors of assessing a firm's future value potential (e.g. Möller \& Törrönen 2003) and, thus, supplier selection in business markets (e.g. Golfetto \& Gibbert 2006). Using the terminology of Ritter (2006), we are referring to process and market competencies in particular (i.e., routines related to the properties and characteristics of the firm's value-creation process and the value transfer between the firm and its environment) in this study. 
There is an emerging discussion within market-orientation research, as originated by Kohli and Jaworski (1990) and Narver and Slater (1990), on the moderating effects of environmental variables on the relationship between market orientation and business performance (Kaynak \& Kara 2004; Han, Kim \& Srivastava 1998). However, much remains unsettled, while the same applies to contextual moderation of performance with regard to other marketing phenomena, (cf. Auh \& Menguc 2007; Avlonitis \& Gounaris 1997). This research type benefits particularly from studies in different business contexts (industry, national and/or cultural), since they enable testing procedures for the generalizability of results. To enhance the understanding of contextual moderation, we examine performance mechanism in a cross-country setting, among "culturally engineering-oriented" countries.

The role of innovation and innovation orientation in the market orientation versus performance puzzle is also somewhat unclear. We are accustomed to thinking that innovation works positively both directly and indirectly (e.g., through entrepreneurship) with market orientation (Hult, Hurley \& Knight 2004; Manu 1992). Thus, these orientations may be complementary, as Menguc and Auh (2006) suggest. However, in practice, technology-oriented firms may not value market-based innovations, because such innovations can be considered technologically too straightforward (Zhou, Yim \& Tse 2005). Therefore, companies may want to drive the market, rather than be marketdriven (e.g. Carrillat, Jaramillo \& Locander 2004). While market-driven refers to a business logic that is based on understanding and reacting to the preferences and behaviors of players within a given market structure, market-driving implies influencing 
the structure of the market and/or the market players' behaviors so that the business' competitive position is enhanced (Jaworski et al. 2000). By doing so, market-driving potentially allows firms to better match customer value opportunities with their own capabilities (Carrillat et al. 2004). Berghman, Matthyssens and Vandenbempt (2006) suggest that this might be especially true for companies that interact with professional customers.

Market-driven firms are superior in terms of market-focused learning capabilities and marketing capabilities (Day 1994). Further, when these capabilities are deeply embedded within the organization, all functional activities and organizational processes are better directed toward anticipating and responding to changing market requirements (Weerawardena \& O’Cass 2004). However, in today's competitive business arena, companies are continuously challenged to anticipate rather than follow changes in customer value and firms must be designed so that they can quickly absorb new knowledge into the organization and thus, create new customer value while concurrently exploiting existing best practices (Berghman et al. 2006; O'Reilly \& Tushman 2004). In the present study, emphasis is placed on market-driven strategic marketing.

We place a strong emphasis on the effectiveness, or strategic performance that results from performing the right marketing activities (Drucker 1966). As Pfeffer and Salancik's (1978) point out, however, effectiveness is not a universal concept since the effectiveness of an organization depends on which group, and with which criteria and preferences, the 
assessment is provided. However, generally what is being produced is just as important as the way in which it is produced (Pfeffer \& Salancik 1978).

Figure 1 illustrates the study's general framework. Accordingly, strategic marketing resources and orientations are assumed to effect company success at both the competitive advantage and performance level. Since business environmental factors, such as national characteristics and market dynamics, inevitably moderate the relationships between strategic marketing and performance, they must be considered as well. Additionally, the leveraging effects of company success in strategic marketing resources and orientations likely exist, but (see e.g. Lovett \& MacDonald 2005), due to the cross-sectional nature of data, this feedback loop must, unfortunately, be ignored.

\section{Place Figure 1 Here}

\section{CONCEPTUAL MODEL AND HYPOTHESES}

The results of certain previous researches are considered in the following, as the hypotheses are developed. Additionally, we provide a brief overview for each of the present study's constructs. All four explanatory constructs of the study are clearly intangible and, thus, cannot be purchased from the marketplace. Despite their intangible nature, benefits to the firm can be considered similar to those provided by tangible 
resources, such as physical assets (Rust, Ambler, Carpenter, Kumar \& Srivastava 2004).

Three dependent variables are included in this study.

\section{Market orientation}

A frequently used definition from Narver and Slater (1990) conceptualizes that market orientation comprises customer orientation, competitor orientation and inter-functional coordination, with long-term and profitability focuses. Hunt and Morgan (1995) further stress the importance of focus on both current and potential markets. Market orientation is inherently a learning orientation (Slater \& Narver 1995), which can be divided into responsive (market-driven) and proactive (market-driving) market orientations, wherein the former attempts to discover, understand and satisfy expressed customer needs, while the latter also latent needs (Narver, Slater \& MacLachlan 2004). Due to recent changes in the business environment, most industries must continuously focus on customer needs and market opportunities (Walker, Mullins, Boyd \& Larréché 2006; Menguc \& Auh 2006). Customers also seek innovative suppliers that offer new value concepts or total solution packages (Berghman et al. 2006). Thus, firms that provide superior customer value are in strategic competitive positions. We believe that these considerations apply to companies in "engineering countries" in particular, and for this reason, include market orientation in our analytic framework.

It is argued that market orientation facilitates clarified focus and vision in terms of an organization's strategy, which consequently leads to superior performance (Kohli \& 
Jaworski 1990). Although the findings on this relationship are inconclusive (e.g. Tuominen et al. 2005), several empirical studies (e.g., Narver \& Slater 1990; Jaworski \& Kohli 1993; Han et al. 1998; Matsuno et al. 2002) with relatively consistent results provide support — both in absolute and relative terms - to the existence of a positive relationship between the constructs. Further, resources that enable value creation, such as market orientation, are potential sources of competitive advantage that require high barriers for competitors to match (Fahy \& Smithee 1999; Noble, Sinha \& Kumar 2002). The following set of hypotheses is thus developed:

$\mathbf{H}_{1 \mathbf{1 a}, 1 \mathbf{1 b}, \mathbf{1 c}}$ : Market orientation has a positive relationship to market performance $\left(\mathbf{H}_{\mathbf{1 a}}\right)$, financial performance $\left(\mathbf{H}_{\mathbf{1 b}}\right)$ and (sustainable) competitive advantage $\left(\mathbf{H}_{\mathbf{1 c}}\right)$.

\section{Innovation orientation}

A key component of success for industrial firms is the extent of their innovativeness, which relates to the firm's capacity to engage in innovation; introduction of new processes, products, or ideas in the organization and market (Hult et al. 2004). Innovation also calls for innovation orientation, which refers to "the knowledge structure that permits the recognition of market dynamism and then provides a knowledge template to develop the required process and to build a firm's dynamic capabilities" (Siguaw et al. 2006). As a result, firms with high innovation orientation differentiate themselves primarily by the degree of innovation in their offerings (Hooley \& Greenley 2005). Moreover, Howard (1983) argues that process innovation is a prerequisite for successful product innovation. Recently, Siguaw et al. (2006) further argue that a firm's long-term 
success likely relies more on overall firm-level innovation orientation than on specific innovations. Due to high R\&D investments and the inherent importance of innovativeness in "engineering countries," innovation orientation seems to support its place within the framework of this study.

Hult et al. (2004) argue that innovative activities are generally important to the success of the industrial firm, while innovation orientation is evidenced to have a positive relationship with competitive advantage and related isolation mechanisms (Hooley \& Greenley 2005; Siguaw, et al. 2006; Weerawardena \& O'Cass 2004), new-product success superiority (Narver et al. 2004) and financial performance (Hooley et al. 2005). Consistent findings show that companies that innovate are in better positions than those that do not (Jin, Hewitt-Dundas \& Thompson 2004; Han et al. 1998; Matsuno et al. 2002). Moreover, due to the complex interplay of resources that is required for effective innovation, a position based on innovation is likely to enjoy a high degree of defensibility (Hooley \& Greenley 2005). It is, therefore, hypothesized that:

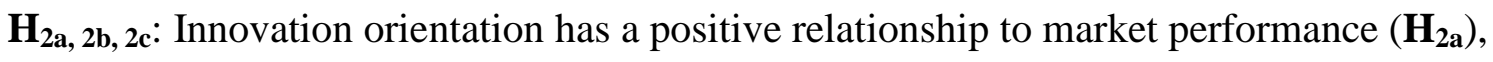
financial performance $\left(\mathbf{H}_{\mathbf{2 b}}\right)$ and (sustainable) competitive advantage $\left(\mathbf{H}_{\mathbf{2} \mathbf{c}}\right)$.

\section{Marketing capabilities}

Marketing capabilities refer to a firm's ability to use its resources in competitively advantageous ways (Barney 1991; Wernerfelt 1984). Further, Möller (2006) suggests that an individual organization's value creation is based on its collection of capabilities or 
competencies. Several categorizations for market-related and marketing capabilities are advanced (e.g. Vorhies \& Morgan 2005; Möller \& Törrönen 2003; Day 2000). In his seminal article on market-driven capabilities, Day (1994) suggests there are three kinds of capabilities in every firm - depending on orientation and focus of the defining processes - that potentially provide competitive advantages: outside-in (an external emphasis), inside-out (an internal emphasis) and spanning capabilities. His framework proposes that organizations can become more market-oriented by identifying and building market-based capabilities. We incorporate outside-in and inside-out capabilities in the present study and, thus, consider the extremes along the capability continuum.

According to Day (1994), outside-in capabilities connect the processes that define other organizational capabilities to the external environment and enable businesses to compete by anticipating market requirements ahead of competitors, thus creating durable relationships with customers and other stakeholders. Outside-in capabilities are necessary, for example, in market sensing and customer-relationship building activities (Day 1994). Further, as externally focused capabilities, they involve changes to the offering itself and customer delivery, or a better understanding and exploitation of the firm's product markets (Blois \& Ramirez 2006). Without these capabilities, on the other hand, firms are likely to become out of touch with their markets, and lose their ability to react or innovate (Berghman et al. 2006). Inside-out capabilities, for their part, are highly emphasized internally. They are developed or acquired mainly to enhance the firm's operational performance and unfold as to what the firm is good at and capable of doing (Blois \& Ramirez 2006). These may relate to, among others, technology development, 
organizational processes and human resources management, and thus, increase efficiencies in the delivery process and reduce operating costs (Day 1994).

Hunt and Morgan (1995) argue that "a comparative advantage in resources ... can translate into a position of competitive advantage in the marketplace and superior financial performance." Moreover, the development of marketing competence is seen to increase a focal firm's bargaining power and reduce its dependence on industrial customers (Zerbini et al. 2007). Day (1994) further argues that mastery of distinctive capabilities and performance superiority are directly connected, which is supported by Varadarajan and Jayachandran (1999) and Vorhies (1998). Additionally, Vorhies and Morgan (2005), Nath, Nachiappan and Ramanathan (2010) and Tuominen et al. (2005) find a positive association between inside-out capabilities and performance superiority. These arguments lead us to hypothesize that:

$\mathbf{H}_{\mathbf{3 a}, \mathbf{3 b}, \mathbf{3 c}}$ : Inside-out capabilities have positive relationships to market performance $\left(\mathbf{H}_{\mathbf{3 a}}\right)$, financial performance $\left(\mathbf{H}_{\mathbf{3 b}}\right)$ and (sustainable) competitive advantage $\left(\mathbf{H}_{\mathbf{3 c}}\right)$.

Moreover, according to Hooley et al. (2005) and Nath et al. (2010), outside-in capabilities statistically relate significantly positively to market performance, which positively relates to a firm's financial performance. Tuominen et al. (2005), for their part, empirically verify a positive relationship between outside-in capabilities and innovativeness - a near proxy for innovation orientation — which further drives performance. Thus, we hypothesize that: 


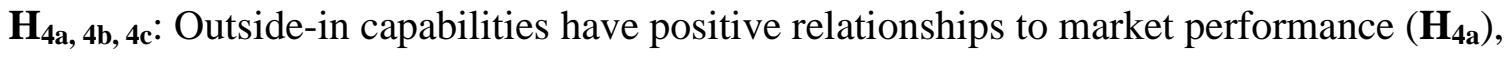
financial performance $\left(\mathbf{H}_{\mathbf{4 b}}\right)$ and (sustainable) competitive advantage $\left(\mathbf{H}_{\mathbf{4 c}}\right)$.

\section{Sustainable competitive advantage}

Sustainable advantages are often achieved through a combination of the strategic insight and valuable, rare, imperfectly imitable and non-substitutable resources required to implement a chosen strategy. In his classic article, Barney (1991) states that sustainable competitive advantages cannot be bought from the marketplace. Instead, sustainability of competitive advantage is said to be achieved through the deployment of isolating mechanisms that protect the advantage, such as causal ambiguity (Lippman \& Rumelt 1982), resource interconnectedness, and path dependency (Fahy \& Smithee 1999; Hunt \& Morgan 1995). Sustainability occurs only when a firm's comparative resource advantages continue to yield a competitive advantage position despite competitor actions (Hunt \& Morgan 1995). To date, sources of competitive advantage in marketing are not sufficiently clarified (Srivastava et al. 1998; Morgan et al. 2002). Thus, including competitive advantage to our framework as a second, non-financial, intermediate performance construct is relevant because it then better captures the potential mechanisms through which orientations and capabilities affect business performance.

In order to achieve superior market performance and above-average returns, firms must develop and sustain competitive advantages (Slater \& Narver 1994; Fahy \& Smithee 1999). For example, a company that has cost leadership can sell its offerings at low prices 
without sacrificing profitability. Isolating mechanisms, such as causal ambiguity, also create barriers to imitation that further increase the business performance impact of competitive advantages (Fahy \& Smithee 1999). Empirically, Hult and Ketchen (2001) show that positional advantage positively affects performance. Thus, we hypothesize the following:

$\mathbf{H}_{\mathbf{5 a}, \mathbf{5 b}}$ : (Sustainable) competitive advantage has a positive relationship to market performance $\left(\mathbf{H}_{\mathbf{5 a}}\right)$ and financial performance $\left(\mathbf{H}_{\mathbf{5 b}}\right)$.

\section{Business performance}

Performance outcomes result from market successes or when market positions are achieved (Day \& Wensley 1988) and fundamentally change over time (Rust et al. 2004). Therefore, performance measures should capture business performance at both current and future levels. More explicitly, a broad and well-balanced performance conceptualization, including financial and non-financial measures, will help marketers to fully understand the performance consequences of their strategies (Varadarajan \& Jayachandran 1999). Thus, we incorporate both financial and market performance entities in the present study. Here, the term "business performance" is used as a general performance construct to capture both the market and financial aspects of performance. Financial performance literally refers to financial measures, such as profit margin and return on investment, whereas market performance implies measures such as market share and sales volume. 
Every firm should, in principle, seek profitable growth over maximum sales alone. For example, PIMS studies find that a strongly positive link exists between market share and ROI measures (Buzzell \& Gale 1987). Similar results are achieved in many other studies as well (e.g., Srivastava et al. 1998; Hooley et al. 2005). Further, Hooley et al. (2001) argue that superior market performance likely results in superior financial performance. Thus, we hypothesize that:

$\mathbf{H}_{6}$ : Market performance has a positive relationship to financial performance.

\section{Contextual moderation}

The above hypotheses are tested within a full three-country sample (Austria, Finland and Germany). The robustness of the notion "engineering country," i.e. the homogeneity of the countries in terms of the generalizability of results across the countries, is also tested within the three individual countries. We start with the hypothesis that engineering orientation is a dominant characteristic as a contextual moderator and, thus, cross-country sensitivity in the examined relationships is not present. Following this line of reasoning, we hypothesize that:

$\mathbf{H}_{7}$ : The results of this study are invariant among the three individual "engineering countries."

In the case Hypothesis 7 is not supported, we examine significant differences between the countries. 


\section{METHODOLOGY}

To test the literature-based hypotheses, an empirical study is performed. The data used in this study is gathered by questionnaire during the 2002-2003 period, which surveys small, medium and large firms in business and consumer products and services in Austria, Finland and Germany. The data set, as is this study, is part of the worldwide Marketing in the 21st Century Program, coordinated by Aston Business School in the UK. The sampling frame is supplied by national research institutes, while sampling is undertaken based on quotas for firm size, industry and market type.

A total of 976 usable responses are received: 249 from Austria, 327 from Finland and 400 from Germany. The response rate in each of the countries is greater than $20 \%$. Companies in B-to-B goods or B-to-B services sector total $57.9 \%$ of the sample. We do not find significant differences in means between early and late respondents on the scales studied, which indicates that non-response bias is not likely a problem (Armstrong \& Overton 1977). All measurement items are measured on subjective five- or seven-point Likert-type scales, mainly related to a company's primary competitors. This makes sense as, e.g., due to varying competitive characteristics or cultural issues, certain metrics in one industry or country may be interpreted as very good, while only moderate or even poor in others (Vorhies \& Morgan 2003). Further, subjective measures are more flexible than objective ones in capturing complex dimensions of performance (González-Benito \& González-Benito 2005). 
Based on a review of the literature, we use existing scales from prior research, with two exceptions: innovation orientation and competitive advantage. As proposed by Narver and Slater (1990), 14 scale items are used to measure market orientation. While organizational innovation is extensively researched in recent years (e.g., Hurley \& Hult 1998; Han et al. 1998; Siguaw et al. 2006), high-quality scales for innovation orientation are not yet available because of rather unsystematic empirical explorations of the degree of innovativeness and related concepts. Therefore, in the present study, items for the innovation orientation construct are developed for the research questions at hand. Following a review of the literature in marketing and organizational behavior, as well as in-depth interviews with marketing managers in the UK, a number of potential items are generated. This item pool is then refined through the expert opinions of marketing scholars in several European countries and, following analysis of the pilot data, a seminal questionnaire is further refined. The four-item scales for inside-out capabilities and outside-in capabilities are previously validated by Greenley, Hooley and Rudd (2005).

Dependent latent variables are influenced by explanatory variables in the structural model, either directly or indirectly (Kline 2005). Items for competitive advantage are also developed for the purposes of this study. Extensive literature review of the resourcebased view of firms is performed to operationalize how competitive advantage is achieved and protected in companies. High scores on the competitive advantage scale suggest that a firm achieves superior market advantages of which competitors are unable to duplicate in terms of the firm's innovations and distinctive capabilities. For 
performance constructs (market performance and financial performance), five frequently used and validated (e.g., Hooley et al. 2005) items are selected for use.

When applying statistical methods to the data, descriptive frequency analysis is first conducted to determine to what extent results can be generalized. Subsequently, confirmatory factor analysis (CFA) is applied. Analysis is conducted as if the answers are given at continuous scales, although the scales are essentially ordinal. All the constructs are treated as reflective. In terms of inside-out capabilities, we consider general management capability and the corresponding corporate culture to set the scene for several distinct capabilities. For others, the reflective nature of the constructs is more or less evident. Since our factor structure is based on previous studies, it is consistent to use CFA in the model's development and assessment. Additionally, exploratory factor analysis (EFA) is used to test the discriminant validity of the model. Structural equation modeling (SEM) is finally used to specify which latent, reflective constructs directly or indirectly influence changes in the values of other latent constructs in the model (Kline 2005). Potential contextual differences are tested by multiple-group SEM.

\section{ANALYSIS AND RESULTS}

Appendix A presents the distribution of companies in the full sample and in each subsample, based on industry type, size, market characteristics and market position. The distributions are visibly alike. Thus, results between the sub-samples are assumed to be unbiased and comparable. 
For scale construction and validation, confirmatory factor analysis (CFA) is used. All three countries are included in the analysis. Approximately half of the original items are excluded from the model to achieve the appropriate levels of unidimensionality (thresholds for both loadings and communalities are set at 0.40). See Appendix B for a final, reduced list of items in each construct. The fit indices of the model are then found acceptable: root mean square of approximation $(\mathrm{RMSEA})=0.048$; goodness of fit index $(\mathrm{GFI})=0.95$; comparative fit index $(\mathrm{CFI})=0.98$; and non-normed fit index $(\mathrm{NNFI})=$ 0.97. Additionally, correlations between the constructs in Table 1 are reasonably low and EFA offers strong support to the model's validity. Further, values for composite reliabilities and average variances extracted are almost solely above the respective thresholds of 0.6 and 0.5, as recommended by Diamantopoulos and Siguaw (2000). Thus, a set of reliable and valid metrics for the constructs is provided (Kline 2005).

\section{Place Table 1 Here}

The present study's hypotheses are tested simultaneously using LISREL 8.80 and the final model is presented in Figure 2. Covariance matrix and maximum likelihood estimation procedure are used in conducting structural equation modeling. The overall model fit indices refer to a good general fit between the model and the data. The previously developed model is also applied individually to all three sample countries. Fit indices and correlations of the models indicate that they can well be used to test the 
national context's moderating effect on performance. Fit indices for each sample country are available in Appendix C.

\section{Place Figure 2 Here}

As seen in Figure 2, market orientation has a significant, but negative relationship to market performance $(\beta=-0.08)$, and thus does not provide support for H1a. Also, its relationship with financial performance $(\beta=0.00)$ does not support $\mathrm{H} 1 \mathrm{~b}$, whereas $\mathrm{H} 1 \mathrm{c}-$ market orientation's positive link to competitive advantage — is moderately supported ( $\beta=0.08)$. Innovation orientation positively relates to market performance $(\beta=0.15)$ and competitive advantage ( $\beta=0.38$ ), which support $\mathrm{H} 2 \mathrm{a}$ and $\mathrm{H} 2 \mathrm{c}$, respectively. However, a positive direct link between innovation orientation and financial performance $(\beta=-0.02)$ is not found, and therefore, $\mathrm{H} 2 \mathrm{~b}$ is not supported. Strong indications for the positive effect of inside-out capabilities and market performance $(\beta=0.30)$ and financial performance ( $\beta=0.21)$ are identified to support $\mathrm{H} 3 \mathrm{a}$ and $\mathrm{H} 3 \mathrm{~b}$, respectively. However, results do not support $\mathrm{H} 3 \mathrm{c}$, inside-out capabilities' positive relation to competitive advantage $(\beta=-0.05)$. Outside-in capabilities do not positively relate to market performance $(\beta=0.02)$ and financial performance ( $\beta=-0.01)$ and thus, support for $\mathrm{H} 4 \mathrm{a}$ and $\mathrm{H} 4 \mathrm{~b}$ is not achieved. Instead, a positive relationship to competitive advantage is identified $(\beta=0.08)$ and, therefore, $\mathrm{H} 4 \mathrm{c}$ is supported. Competitive advantage is not statistically significant in its positive relation to market performance, $(\beta=0.07)$ but only with financial performance ( $\beta=0.10$ ). Therefore, H5a is not supported, while H5b is supported. Finally, very strong 
support is provided for the positive relationship between market performance and financial performance. Thus, H6 is supported $(\beta=0.44)$. The explanatory power $\left(R^{2}\right)$ of the model is $33 \%$.

In order to test the robustness of the results, we examine the model by carrying out crosscountry comparisons. The results of country comparisons are not severely biased since problematic group dominance (Kline 2005) is not in place for any of the three countries. Fortunately, equalities of factor structures among engineering countries are supported, thus, further justifying national comparisons. Regression coefficient matrices are found to be statistically invariant at the .05 confidence level between Austria and Germany $(\mathrm{p}=0.10)$, but to vary between Finland and Austria $(\mathrm{p}=0.034)$ and between Finland and Germany $(\mathrm{p}=0.0021)$. In addition to hypotheses results, Table 2 presents path coefficients for each sample country and comparison of their statistical differences. Among the individual engineering countries, all but one statistically significant relationship is positive, and therefore, coherent with the underlying theory. The comparison part of the table can be interpreted so that, for example, the regression coefficient between market orientation and market performance is statistically significant (at confidence level 0.05) in that it is less negative in Austria than in Finland. Direct comparisons between regression coefficients can be made since the models are similar across all sample countries.

Place Table 2 Here 
Table 3 presents total effects for the study constructs on financial performance. Fullsample results indicate that only inside-out capabilities and innovation orientations have considerable effects on financial performance. Germany is the most effective in terms of its market orientation and outside-in capabilities, while Austria is effective in terms of innovation orientation and Finland is the best in benefiting from inside-out capabilities. In total, Germany appears to be the most effective "strategic marketer" among the engineering countries studied, while Finland the least effective. This can also be identified from Table 3. Business environmental differences seem to influence the impact of strategic marketing factors (e.g. Hooley et al. 2001, Slater \& Narver 1994), and hypothesis H7 is thereby not supported. Therefore, global companies are forced to take environmental differences, such as customer needs, into serious consideration.

Place Table 3 Here

\section{DISCUSSION AND CONCLUSIONS}

\section{Theoretical implications}

This study, as performance studies in general, contributes to both managerial decisionmaking and academic discussion by offering important empirical evidence about key company success factors. The results of such studies guide what to measure, thus, 
improving the use of truly significant metrics in marketing performance assessment (Morgan et al. 2002). Examination of the context-dependence of the results provides further contribution as to which issues are of special importance to international companies. Market differences must be accounted for, even in such relatively homogenous countries, from a global point of view, as Austria, Finland and Germany.

Without a doubt, the results of our quantitative analysis are the most important contribution of this study. As the results only support half of the literature-based hypotheses ( 8 of 16), a number of interesting contradictions and new important details about the influence of strategic marketing elements on company performance can be identified. This is despite the fact that results from the PIMS studies—positive relationship between market and financial performances—are strongly supported. Comparison of the "engineering countries" provides some entirely new results as well. Considering our characterization of an "engineering country," the findings can be generalized— naturally, with caution—to, among others, countries like Sweden and Japan.

The key contradiction of the study is the low impact of market orientation on financial performance, which is not assumed, as several previous studies propose the link to be strongly positive. Also, this result is surprising in light of a recent, general development of increased customer focus (cf. Walker et al. 2006). Nevertheless, as proposed by Dierickx and Cool (1989), it is characteristic to market orientation that it also contributes to the accumulation of other organizational resources and increases their value. In the 
context of this study, then, a potential explanation is that the influence of market orientation is channeled through outside-in capabilities. Theoretically, one can conceive these capabilities to be manifestations of market orientation. That is, market orientation can be their antecedent. Moreover, market and innovation orientation are likely to affect firm performance over the longer term than inside-out capabilities in particular, which essentially increase the efficiency of the firm's processes and, thus, improve short-term performance. These propositions require further research.

Another interesting result is the weak relationship found between outside-in marketing capabilities and the performance measures compared to the strong role of inside-out capabilities. One interpretation is that, in well-developed markets, customer-relating skills are a necessity that does not distinguish between high- or low-performing companies. What seem crucial are firm innovativeness and the operational efficiency, measured by inside-out capabilities. The latter are identified as the most effective factors on financial performance in each sample country. Results should not, however, be taken as given since prior evidence (e.g., Nath et al. 2010) suggests that efficient integration of marketing and operational capabilities leads to improved organizational performance, while operational success is a prerequisite for marketing success. Considering this, the results of the present study are understandable, as technological innovations and operational efficiencies arguably receive more managerial focus than marketing in “engineering countries." Having inside-out capabilities that effectively drive performance, the task now becomes to build equally beneficial outside-in capabilities. 
In total, the outcomes of this study are not unheard of; for example, Tuominen et al. (2005) find quite similar relationships in their study of companies in Finland and New Zealand. Further, the results are in line with Fahy et al. (2000), who suggest that marketing capabilities relate to performance with a strongly positive association. In terms of business environmental sensitivity, the present study's findings support the outcomes of, among others, Manu (1992) and Song and Parry (1997).

What is also notable is that several statistically significant deviations in structural path magnitudes among the sample countries are identified. The total effect of strategic marketing on firm financial performance is also found to be sensitive to countries under study; strongest in Germany while weakest in Finland. Thus, our critical test suggests that the results of the present study cannot be directly generalized into individual countries as sensitivity by sample country is identified even among highly homogenous countries. While it seems clear that different characteristics of country-specific business environments influence the effectiveness of strategic marketing factors, one cannot say for certain whether successes in these countries are caused predominantly by superior strategic marketing practices or by favorable business environments, and whether e.g., different orientations are causes of superior performance or its outcomes (cf. Avlonitis \& Gounaris 1997). On a theoretical level, the country specificity of our results is a major finding that challenges the widely assumed generality of the strategic marketingperformance relationship and provides additional criticism of cross-sectional analysis.

\section{Managerial implications}


This study provides new insights as to which issues companies should concentrate on in order to improve their effectiveness in terms of strategic marketing. However, good strategy requires effective implementation in order to result in superior business performance (e.g., Vorhies \& Morgan 2003). Actually, this may be the underlying key to the strongly positive relationships between inside-out capabilities and business performance we identify. Inside-out capabilities are most closely related to strategy implementation of all the constructs used in this study.

How should managers then conduct their strategic marketing to achieve the best possible outcomes as a result? While others might try to learn from Finnish companies to develop effective inside-out capabilities, German companies provide benchmark opportunities as to market orientation and outside-in capabilities and Austrian companies as to innovation orientation. In general, in light of the results, Germany is the country from which best practices should be modeled, although there seems to be considerable areas of improvement in terms of outside-in capabilities, market orientation and innovation orientation in all sample countries. This indicates that customers and market characteristics remain inadequately addressed in engineering country companies. Thus, it is reasonable to suggest that, in general, more marketing training should be given to engineers in order to improve their regard and mindsets for marketing. Although the current focus is changing from features offerings to customer needs fulfillment, substantial work remains undone. 
A market-oriented culture likely should be complemented by a spirit of entrepreneurship and an appropriate organizational climate, as suggested by Slater and Narver (1995). Additionally, management should note whether their business logic is proactive or reactive, and ensure that a match exists between the type of business logic adopted and the type of market orientation emphasized (Tuominen et al. 2004). Moreover, the importance of collaboration between marketing and R\&D services can be emphasized, since new products are more successful if based on both technology use and consumer information (Gotteland \& Boulé 2006; Siguaw et al. 2006). Organizations can also learn from markets and develop effective strategies to disseminate the acquired knowledge, such as fine-tuned CRM systems, since such learning can indeed be a source of competitive advantage (e.g., Slater \& Narver 1995). We propose that companies also develop a clear understanding of their capabilities and competencies, especially in terms of customer value-addition. Although mere possession of superior resources does not guarantee competitive advantage for a firm (Nath et al. 2010), combining this understanding of competencies with customer insight is suggested to be the basis for growth and profitability (Ritter 2006).

Finally, for any strategy to be sustainable, it must be based on firm resources and capabilities. Further, strategic marketing investments and activities reduce business risks (Rust et al. 2004). Thus, in principle, human resources developments are worthwhile efforts. Nevertheless, developing distinctive capabilities binds considerable amount of organizational resources, and thus, involves a trade-off in terms of which capabilities to develop (Weerawardena \& O'Cass 2004). Moreover, as one of the most significant 
management challenges lies in balancing devotion to the exploration of new opportunities and exploitation of existing capabilities, how should firms then divide their investments in capabilities? O'Reilly III and Tushman (2004) argue that most successful companies master refining their current offerings, but experience trouble when pioneering radically new ones. Thus, are inside-out capabilities a necessary, but insufficient condition for business success? Our results do not shed light on this issue, but since inside-out capabilities are highly effective, firms in engineering-like countries should place strong emphasis on trying to enhance their levels and effectiveness of outside-in capabilities. Employees should also be encouraged to adopt innovation-oriented work methods. Relying on O'Reilly III and Tushman (2004), these changes could result in enduring performance superiority in terms of both market-based and financial metrics. Naturally, as firms engage in different kinds of collaboration and outsourcing activities, it may not be necessary to develop required knowledge bases and resources internally. Whatever a firm's competencies, the managerial challenge is to translate them into relevant customer arguments (Ritter 2006).

\section{Limitations and avenues for further research}

While cross-sectional data does not capture the sequential, temporal order of causality or the dynamics that the models in this study conceptually assume, "a piece of property in its distant past may be now providing it a unique source of comparative advantage and influencing its size, scope, or profitability" (Hunt \& Morgan 1995). For example, Gilbert and Bower (2002) argue that the total value of innovation is not always immediately 
apparent, but rather only realized over time and after competencies are built and actualized; and the same applies to market orientation (Cadogan, Diamantopoulos \& Siguaw 2002). Additionally, the analysis of the present study is based on managerial perception data, which may have an effect on the results obtained (e.g., Jaworski \& Kohli 1993; Barney 1991; Neely 2002) due to the subjective, rather than objective nature of the data. It might be especially challenging for managers to self-report the levels of certain organizational determinants or their relative advantages over a firm's primary competitors.

Further, principles of marginal utility theorem may somewhat bias the magnitudes of path coefficients; for example, relationships between capabilities and business performance are likely to be non-monotonic as the higher the current level, the harder they are to improve. Thus, the performance impact of constructs with high average points - in this case, market orientation and outside-in capabilities - is somewhat downward biased, and vice versa. An awareness of the potential for the significant variance in performance, market position and profitability of firms from one year to another is yet another issue to consider. Also, non-rational activities sometimes cause success, so that a high-performing product or company may have little to do with management effectiveness.

Since factors under examination in this study naturally are not entirely distinctivealthough considerable multicollinearity is not identified - taking the results as-is may lead to the fallacy of oversimplification (cf. Vorhies \& Morgan 2005). For example, Day (1994) argues that market-driven organizations have superior market-sensing, customer- 
linking and channel-bonding (i.e., outside-in marketing) capabilities, as empirically supported by Hooley et al. (2005). Therefore, our results may not suggest that highly developed inside-out capabilities alone are a sufficient condition for effective long-term business performance. Instead, its role as a complementary factor to other performancedriven constructs, such as firm orientation and resources, may be considerable. Other path coefficient results may also be interpreted accordingly, so that e.g., organizations without the capacity to innovate may invest time and resources in studying markets, but remain unable to translate this knowledge into practice (Hult et al. 2004).

To outline some potential avenues for further research, it is of great interest to conduct a study wherein the data used for the present study is used as reference data to acquire new information, to aid in the application of a longitudinal research setting. This will help, for example, in finding sources of sustainable competitive advantages and to potentially shed light on the longer-term success factors that affect business performance. A new data set is welcomed as well, because the factors in this study are deeply imbedded and slowly evolving in companies (Winter 2003). Although statistical models will, thus, become more complex, including one or two operational variables in the research setting will also help to clarify the relative effect of strategic marketing issues. Moreover, among others, learning, entrepreneurial and strategic orientations and spanning capabilities - those left outside the scope of this paper in order to keep the analysis as interpretable as possiblecan be employed. Additionally, by exploring the potential moderating effects on business performance of strategic marketing more comprehensively, empirical studies with focus on result sensitivity with regard to industry type, market position and company size, 
among others, will be both interesting and relevant. Finally, testing the generalizability of the results of the present study will now be tempting; e.g., Swedish or Japanese data can be used, as they are also counties that benefit from high $R \& D$ investments and propensity to innovate.

\section{ACKNOWLEDGEMENTS}

This study is a part of the StratMark project, financed by the Liito program of the Finnish Funding Agency for Technology and Innovation. 
Appendix A. Firm characteristics in the research sample

\begin{tabular}{|c|c|c|c|c|c|c|c|c|}
\hline \multirow[b]{2}{*}{ Industry Type } & \multicolumn{2}{|c|}{ Austria } & \multicolumn{2}{|c|}{ Germany } & \multicolumn{2}{|c|}{ Finland } & \multicolumn{2}{|c|}{ Full Sample } \\
\hline & Frequency & Percent & Frequency & Percent & Frequency & Percent & Frequency & Percent \\
\hline Business Goods & 61 & 24.50 & 131 & 32.75 & 144 & 44.04 & 336 & 34.43 \\
\hline Consumer Goods & 63 & 25.30 & 108 & 27.00 & 107 & 32.72 & 278 & 28.48 \\
\hline $\begin{array}{l}\text { Business } \\
\text { Services }\end{array}$ & 49 & 19.68 & 117 & 29.25 & 63 & 19.27 & 229 & 23.46 \\
\hline $\begin{array}{l}\text { Consumer } \\
\text { Services }\end{array}$ & 39 & 15.66 & 42 & 10.50 & 6 & 1.83 & 87 & 8.91 \\
\hline Other & 37 & 14.86 & 2 & 0.50 & 7 & 2.14 & 46 & 4.71 \\
\hline \multirow[b]{2}{*}{$\begin{array}{l}\text { Number of } \\
\text { Employees }\end{array}$} & \multicolumn{2}{|c|}{ Austria } & \multicolumn{2}{|c|}{ Germany } & \multicolumn{2}{|c|}{ Finland } & \multicolumn{2}{|c|}{ Full Sample } \\
\hline & Frequency & Percent & Frequency & Percent & Frequency & Percent & Frequency & Percent \\
\hline Fewer than 20 & 22 & 8.84 & 22 & 5.50 & 12 & 3.67 & 56 & 5.74 \\
\hline $20-99$ & 119 & 47.79 & 126 & 31.50 & 147 & 44.95 & 392 & 40.16 \\
\hline $100-999$ & 86 & 34.54 & 174 & 43.50 & 125 & 38.23 & 385 & 39.45 \\
\hline \multirow[t]{2}{*}{ More than 1000} & 22 & 8.84 & 78 & 19.50 & 43 & 13.15 & 143 & 14.65 \\
\hline & \multicolumn{2}{|c|}{ Austria } & \multicolumn{2}{|c|}{ Germany } & \multicolumn{2}{|c|}{ Finland } & \multicolumn{2}{|c|}{ Full Sample } \\
\hline $\begin{array}{c}\text { Market } \\
\text { Characteristics } \\
\end{array}$ & Frequency & Percent & Frequency & Percent & Frequency & Percent & Frequency & Percent \\
\hline Emerging & 21 & 8.43 & 20 & 5.00 & 19 & 5.81 & 60 & 6.15 \\
\hline Growing & 139 & 55.82 & 192 & 48.00 & 162 & 49.54 & 493 & 50.51 \\
\hline Mature & 60 & 24.10 & 94 & 23.50 & 128 & 39.14 & 282 & 28.89 \\
\hline \multirow[t]{2}{*}{ Declining } & 29 & 11.65 & 94 & 23.50 & 18 & 5.50 & 141 & 14.45 \\
\hline & \multicolumn{2}{|c|}{ Austria } & \multicolumn{2}{|c|}{ Germany } & \multicolumn{2}{|c|}{ Finland } & \multicolumn{2}{|c|}{ Full Sample } \\
\hline Market Position & Frequency & Percent & Frequency & Percent & Frequency & Percent & Frequency & Percent \\
\hline $\begin{array}{c}\text { Market/Niche } \\
\text { Leader }\end{array}$ & 104 & 41.77 & 166 & 41.50 & 149 & 45.57 & 419 & 42.93 \\
\hline $\begin{array}{l}\text { Market/Niche } \\
\text { Challenger }\end{array}$ & 98 & 39.36 & 151 & 37.75 & 138 & 42.20 & 387 & 39.65 \\
\hline $\begin{array}{l}\text { Market/Niche } \\
\text { Follower }\end{array}$ & 47 & 18.88 & 83 & 20.75 & 40 & 12.23 & 170 & 17.42 \\
\hline
\end{tabular}


Appendix B. Final measurement items for each construct

\begin{tabular}{|c|c|c|}
\hline $\begin{array}{l}\text { Market } \\
\text { Orientation }^{\mathrm{a}}\end{array}$ & $\begin{array}{l}1 . \\
2 . \\
3 . \\
4 . \\
5 .\end{array}$ & $\begin{array}{l}\text { Our objectives and strategies are driven by the creation of customer satisfaction. } \\
\text { Competitive strategies are based on understanding customer needs. } \\
\text { Business functions are integrated to serve market needs. } \\
\text { Business strategies are driven by increasing value for customers. } \\
\text { Our managers understand how employees can contribute to value for customers. }\end{array}$ \\
\hline $\begin{array}{l}\text { Innovation } \\
\text { Orientation }^{b}\end{array}$ & $\begin{array}{l}2 . \\
3 .\end{array}$ & $\begin{array}{l}\text { We are more innovative than our competitors in deciding what methods to use in } \\
\text { achieving our targets and objectives. } \\
\text { We are more innovative than our competitors in initiating new procedures or } \\
\text { systems. } \\
\text { We are more innovative than our competitors in developing new ways of achieving } \\
\text { our targets and objectives. } \\
\text { We are more innovative than our competitors in initiating changes in the job content } \\
\text { and work methods of our staff. }\end{array}$ \\
\hline $\begin{array}{l}\text { Inside-out } \\
\text { Capabilities }^{c}\end{array}$ & $\begin{array}{l}1 . \\
2 . \\
3 . \\
4 .\end{array}$ & $\begin{array}{l}\text { Strong financial management. } \\
\text { Effective human resource management. } \\
\text { Good operations management expertise. } \\
\text { Good marketing management ability. }\end{array}$ \\
\hline $\begin{array}{l}\text { Outside-in } \\
\text { Capabilities }^{c}\end{array}$ & $\begin{array}{l}1 . \\
2 .\end{array}$ & $\begin{array}{l}\text { Good at creating relationships with key customers or customer } \\
\text { groups. } \\
\text { Good at maintaining and enhancing relationships with key customers. }\end{array}$ \\
\hline $\begin{array}{l}\text { Competitive } \\
\text { Advantage }^{b}\end{array}$ & & $\begin{array}{l}\text { Our competitive advantage is difficult for competitors to copy because it uses } \\
\text { resources only we have access to. } \\
\text { It took time to build our competitive advantage and competitors would find it time- } \\
\text { consuming to follow a similar route. }\end{array}$ \\
\hline $\begin{array}{l}\text { Market } \\
\text { Performance }^{\mathrm{d}}\end{array}$ & & $\begin{array}{l}\text { Sales volume achieved relative to main competitors. } \\
\text { Market share achieved relative to main competitors. }\end{array}$ \\
\hline $\begin{array}{l}\text { Financial } \\
\text { Performance }^{\mathrm{d}}\end{array}$ & & $\begin{array}{l}\text { Profit margins achieved relative to main competitors. } \\
\text { Return on investment relative to main competitors. } \\
\text { Overall profit margins achieved relative to main competitors. }\end{array}$ \\
\hline
\end{tabular}

\footnotetext{
a Seven-point scale ranging from 1 = "not at all" to 7 = "to an extreme extent"

${ }^{\mathrm{b}}$ Five-point scale ranging from 1 = "strongly disagree" to 5 = "strongly agree"

${ }^{c}$ Five-point scale ranging from $1=$ "strong competitor's advantage" to 5 = "our strong advantage"

${ }^{\mathrm{d}}$ Five-point scale ranging from 1 = "much worse" to 5 = "much better"
} 
Appendix C. SEM Goodness of model fit indices $(\mathrm{df}=188)$

\begin{tabular}{lccccc}
\hline Country & Chi`2 $^{\wedge}$ & RMSEA & CFI & NNFI & GFI \\
\hline Austria & 371.61 & 0.063 & 0.95 & 0.94 & 0.88 \\
Finland & 436.95 & 0.064 & 0.96 & 0.95 & 0.89 \\
Germany & 393.69 & 0.052 & 0.97 & 0.97 & 0.92 \\
\hline
\end{tabular}




\section{REFERENCES}

Armstrong, J. S., \& Overton, T. S. (1977). Estimating non-response bias in mail surveys. Journal of Marketing Research, 14 (3), 396-402.

Auh, S., \& Menguc, B. (2007). Performance implications of the direct and moderating effects of centralization and formalization on customer orientation. Industrial Marketing Management, 36 (8), 1022-1034.

Avlonitis, G.V., \& Gounaris, S.P. (1997). Marketing orientation and company performance-Industrial vs. consumer goods companies. Industrial Marketing Management, 26 (5), 385-402.

Ayala, P., Spiechowicz, M., \& Vidaller, J. (2006). EU engineering competitive update. http://ec.europa.eu/enterprise/electr_equipment/engin/engineer_compet_2006.pdf. Accessed 25 March 2009.

Barney, J. (1991). Firm resources and sustained competitive advantage. Journal of Management, 17 (1), 99-120.

Berghman, L., Matthyssens, P., \& Vandenbempt, K. (2006). Building competences for new customer value creation: An exploratory study. Industrial Marketing Management, 35 (8), 961-973.

Blois, K., \& Ramirez, R. (2006). Capabilities as marketable assets: A proposal for a functional categorization. Industrial Marketing Management, 35 (8), 1027-1031.

Bonoma, T.V., \& Clark, B.H. (1988). Marketing performance assessment. Harvard Business School Press. 
Buzzell, R., \& Gale, B. (1987). The PIMS principles: Linking strategy to performance. Free Press.

Cadogan, J.W., Diamantopoulos, A., \& Siguaw, J.A. (2002). Export market-oriented activities: Their antecedents and performance consequences. Journal of International Business Studies, 33 (3), 615-626.

Carrillat, F.A., Jamarillo, F., \& Locander, W.B. (2004). Market-driving organizations: A framework. Academy of Marketing Science Review, 2004 (5), 1-14.

Czarnitzki, D., Ebersberger, B., \& Fier, A. (2007). The relationship between R\&D collaboration, subsidies and R\&D performance: Empirical evidence from Finland and Germany. Journal of Applied Econometrics, 22 (7), 1347-1366.

Dachs, B., Ebersberger, B., \& Pyka, A. (2004). Why do firms co-operate for innovation? A comparison of Austrian and Finnish CIS 3 results. Working Paper Series. University of Augsburg.

Day, G. (1994). The capabilities of market-driven organizations. Journal of Marketing, $58(4), 37-52$.

Day, G.S. (2000). Managing market relationships. Journal of the Academy of Marketing Science, 28 (1), 24-30.

Day, G.S., \& Wensley, R. (1988). Assessing advantage: A framework for diagnosing competitive superiority. Journal of Marketing, 52 (2), 1-20.

Desarbo, W.S., Di Benedetto, A., Song, M., \& Sinha, I. (2005). Revisiting the Miles and Snow strategic framework: uncovering interrelationships between strategic types, capabilities, environmental uncertainty, and firm performance. Strategic Management Journal, 26 (1), 47-74. 
Diamantopoulos, A., \& Siguaw, A. (2000) Introducing Lisrel. SAGE Publications. Dierickx, I., \& Cool, K. (1989). Asset stock accumulation and sustainability of competitive advantage. Management Science, 35 (12), 1504- 1511.

Drucker, P. (1966). The effective executive. Harper \& Row.

Ellis, P.D. (2006). Market orientation and performance: A meta-analysis and crossnational comparisons. Journal of Management Studies, 43 (5), 1089-1107.

Fahy, J., Hooley, G.J., Cox, A.J., Beracs, J., Fonfara, K., \& Snoj. B. (2000). The development and impact of marketing capabilities in Central Europe. Journal of International Business Studies, 31 (1), 63-81.

Fahy, J., \& Smithee, A. (1999). Strategic marketing and the resource based view of the firm. Academy of Marketing Science Review, 1999 (10), 1-18.

Gilbert, C., \& Bower, J.L. (2002). Disruptive change: When trying harder is part of the problem. Harvard Business Review, 80 (5), 94-101.

Golfetto, F., \& Gibbert, M. (2006). Marketing competencies and the sources of customer value in business markets. Industrial Marketing Management, 35 (8), 904-912. González-Benito, O., \& González-Benito, J. (2005). Cultural vs. operational market orientation and objective vs. subjective performance: Perspective of production and operations. Industrial Marketing Management, 34 (8), 797-829.

Gotteland, D., \& Boulé, J-M. (2006) The market orientation-new product performance relationship: Redefining the moderating role of environmental conditions. International Journal of Research in Marketing, 23 (2), 171-185. 
Greenley, G.E., Hooley, G.J., \& Rudd, J.M. (2005). Market orientation in a multiple stakeholder orientation context: implications for marketing capabilities and assets. Journal of Business Research, 58 (11), 1483-1494.

Han, J.K., Kim, N., \& Srivastava, R.K. (1998). Market orientation and organizational performance: Is innovation a missing link? Journal of Marketing, 62 (4), 30-45.

Homburg, C., Workman J.P. Jr., \& Krohmer, H. (1999). Marketing's influence within the firm. Journal of Marketing, 63 (2), 1-17.

Hooley, G., \& Greenley, G. (2005). The resource underpinnings of competitive positions. Journal of Strategic Marketing, 13 (2), 93-116.

Hooley, G.J., Greenley, G., Cadogan, J.W., \& Fahy J. (2005). The performance impact of marketing resources. Journal of Business Research, 58 (1), 18-27.

Hooley, G., Greenley, G., Fahy, J., \& Cadogan, J. (2001). Market-focused resources, competitive positioning and firm performance. Journal of Marketing Management, 17 (56), 503-520.

Howard, J. A. (1983). Marketing theory of the firm. Journal of Marketing, 47 (4), 90100.

Hult, G.T.M., Hurley, R.F., \& Knight, G.A. (2004). Innovativeness: Its antecedents and impact on business performance. Industrial Marketing Management, 33, 429-438.

Hult, G.T.M., \& Ketchen Jr., D.J. (2001) Does market orientation matter? A test of the relationship between positional advantage and performance. Strategic Management Journal, 22 (9), 899-906.

Hunt, S.D., \& Morgan, R.M. (1995). The comparative advantage theory of competition. Journal of Marketing, 59 (2), 1-15. 
Hurley, R.F., \& Hult, G.T.M. (1998). Innovation, market orientation, and organizational learning: An integration and empirical examination. Journal of Marketing, 62 (3), 42-54. Jaworski, B.J., \& Kohli, A.K. (1993). Market orientation: Antecedents and consequences. Journal of Marketing, 57 (3), 53-70.

Jaworski, B., Kohli, A.K., \& Sahay, A. (2000). Market-driven versus driving markets. Journal of the Academy of Marketing Science, 28 (1), 45-54.

Jin, Z., Hewitt-Dundas, N., \& Thompson, N.J. (2004). Innovativeness and performance: Evidence from manufacturing sectors. Journal of Strategic Marketing, 12 (4), 255-266. Kaynak, E., \& Kara, A. (2004). Market orientation and organizational performance: A comparison of industrial versus consumer companies in mainland China using market orientation scale (MARKOR). Industrial Marketing Management, 33 (8), 743-753. Kline, R.B. (2005). Principles and practice of structural equation modeling (2nd edition). The Guilford Press.

Kohli, A.K., \& Jaworski, B.J. (1990). Market orientation: The construct, research propositions, and managerial implications. Journal of Marketing, 54 (2), 1-18. Lippman, S. A., \& Rumelt, R.P. (1982). Uncertain imitability: An analysis of interfirm differences in efficiency under competition. Bell Journal of Economics, 13 (2), 418-438. Lovett, M.J., \& MacDonald, J.B. (2005) How does financial performance affect marketing? Studying the marketing-finance relationship from a dynamic perspective. Journal of the Academy of Marketing Science, 33 (4), 476-485.

Makino, S., Isobe, T., \& Chan, C.M. (2004). Does country matter? Strategic Management Journal, 25 (10), 1027-1043. 
Manu, F.A. (1992). Innovation orientation, environment and performance: A comparison of U.S. and European markets. Journal of International Business Studies, 23 (2), 333359.

Matsuno, K., Mentzer, J.T., \& Özsomer, A. (2002). The effects of entrepreneurial proclivity and market orientation on business performance. Journal of Marketing, 66 (3), $18-32$.

Menguc, B., \& Auh, S. (2006). Creating a firm-level dynamic capability through capitalizing on market orientation and innovativeness. Journal of the Academy of Marketing Science, 34 (1), 63-73.

Miles, R.E., \& Snow, C.C. (1978). Organizational strategy, structure, and process. McGraw-Hill.

Morgan, N.A., Clark, B.H., \& Gooner, R. (2002). Marketing productivity, marketing audits, and systems for marketing performance assessment: Integrating multiple perspectives. Journal of Business Research, 55 (5), 363-375.

Möller, K. (2006). Role of competences in creating customer value: A value-creation logic approach. Industrial Marketing Management, 35 (8), 913-924.

Möller, K.E.K., \& Törrönen, P. 2003 Business suppliers' value creation potential: A capability-based analysis. Industrial Marketing Management, 32 (2), 109-118.

Narver, J.C., \& Slater, S.F. (1990). The effect of a market orientation on business profitability. Journal of Marketing, 54 (4), 20-35.

Narver, J.C., Slater, S.F., \& MacLachlan, D.L. (2004). Responsive and proactive market orientation and new-product success. Journal of Product Innovation Management, 21 (5), 334-347. 
Nath, P., Nachiappan, S., \& Ramanathan, R. (2010). The impact of marketing capability, operations capability and diversification strategy on performance: A resource-based view. Industrial Marketing Management, 39 (2), 317-329.

Noble, C., Sinha, R., \& Kumar, A. (2002). Market orientation and alternative strategic orientations: A longitudinal assessment of performance implications. Journal of Marketing, 66 (4), 25-39.

OECD (2008) OECD Factbook 2008: Economic, environmental and social statistics. http://puck.sourceoecd.org/vl=892083/cl=14/nw=1/rpsv/factbook/ Accessed 25 March 2009.

O’Reilly III, C.A., \& Tushman, M.L. (2004). The ambidextrous organization. Harvard Business Review, 82 (4), 74-81.

O'Sullivan, D., \& Abela, A.V. (2007). Marketing performance measurement ability and firm performance. Journal of Marketing, 71 (2), 79-93.

Pfeffer, J., \& Salancik, G.R. (1978). The external control of organizations: A resource dependence perspective. Harper \& Row.

Randlesome, C. (1994). The business culture in Germany. Oxford: Butterworth. Ritter, T. (2006). Communicating firm competencies: Marketing as different levels of translation. Industrial Marketing Management, 35 (8), 1032-1036.

Rust, R.T., Ambler, T., Carpenter, G.S., Kumar, V., \& Srivastava, R.K. (2004). Measuring marketing productivity: Current knowledge and future directions. Journal of Marketing, 68 (4), 76-89. 
Santos-Vijande, M.L., Sanzo-Pérez, M.J., Álvarez-González, L.I., \& Vázquez-Casielles, R. (2005). Organizational learning and market orientation: interface and effects on performance. Industrial Marketing Management, 34 (3) 187-202.

Shaw, V., Shaw C.T., \& Enke, M. (2003). Conflict between engineers and marketers: the experience of German engineers. Industrial Marketing Management, 32 (6), 489-499.

Siguaw, J.A., Simpson, P.M., \& Enz, C.A. (2006). Conceptualizing innovation orientation: A framework for study and integration of innovation research. Journal of Product Innovation Management, 23 (6), 556-574.

Slater, S.F., \& Narver, J.C. (1994). Does competitive environment moderate the market orientation-performance relationship? Journal of Marketing, 58 (1), 46-55.

Slater, S.F., \& Narver, J.C. (1995). Market orientation and the learning organization. Journal of Marketing, 59 (3), 63-74.

Slater, S.F., Olson, E.M., \& Hult, T.M. (2006). The moderating influence of strategic orientation on the strategy formation capability-performance relationship. Strategic Management Journal, 27 (12), 1221-1231.

Song, M., \& Parry, M.E. (1997). A cross-national comparative study of new product development processes: Japan and the United States. Journal of Marketing, 61 (2), 1-18. Srivastava, R.K., Shervani, T.A., \& Fahey, L. (1998). Market-based assets and shareholder value: A framework for analysis. Journal of Marketing, 62 (1), 2-18. Tuominen, M., Rajala, A., \& Möller, K. (2004). Market-driving versus market-driven: Divergent roles of market orientation in business relationships. Industrial Marketing Management, 33 (3), 207-217. 
Tuominen, M., Matear, S., Hyvönen, S., Rajala, A.., Kajalo, S., Möller, K., Greenley, G.E., \& Hooley, G.J. (2005). Market driven intangibles: Critical indicators for firm performance superiority in small open economies. Proceedings of the ANZMAC Conference. Fremantle, Australia.

Varadarajan, P.R., \& Jayachandran, S. (1999). Marketing strategy: An assessment of the state of the field and outlook. Journal of the Academy of Marketing Science, 27 (2), 120143.

Vorhies, D.W. (1998). An investigation of the factors leading to the development of marketing capabilities and organizational effectiveness. Journal of Strategic Marketing, 6 (1), 3-23.

Vorhies, D.W., \& Morgan, N.A. (2003). A configuration theory assessment of marketing organization fit with business strategy and its relationship with marketing performance. Journal of Marketing, 67 (1), 100-115.

Vorhies, D.W., \& Morgan, N.A. (2005). Benchmarking marketing capabilities for sustainable competitive advantage. Journal of Marketing, 69 (1), 80-94.

Walker, O.C., Mullins, J.W., Boyd, H.W., \& Larréché, J-C. (2006). Marketing strategyA decision-focused approach (5th edition). McGraw-Hill.

Webster, Jr., F.E. (1992). The changing role of marketing in the corporation. Journal of Marketing, 56 (4), 1-17.

Weerawardena, J., \& O’Cass, A. (2004). Exploring the characteristics of the marketdriven firms and antecedents to sustained competitive advantage. Industrial Marketing Management, 33 (5), 419-428. 
Wernerfelt, B. (1984). A resource-based view of the firm. Strategic Management

Journal, 5 (2), 171-180.

Winter, S. (2003). Understanding dynamic capabilities. Strategic Management Journal, 24 (10), 991-995.

Zerbini, F., Golfetto, F., \& Gibbert, M. (2007). Marketing of competence: Exploring the resource-based content of value-for-customers through a case study analysis. Industrial Marketing Management, 36 (6), 784-798.

Zhou, K.Z., Yim, C.K., \& Tse, D.K. (2005). The effects of strategic orientations on technology- and market-based breakthrough innovations. Journal of Marketing, 69 (2), 42-60. 
Table 1. Construct means, standard deviations, reliabilities and correlations

\begin{tabular}{lccccccccccc}
\hline \multicolumn{1}{c}{ Construct } & Mean & $\begin{array}{c}\text { Standard } \\
\text { Deviation }\end{array}$ & $\begin{array}{c}\text { Composite } \\
\text { Reliability }\end{array}$ & $\begin{array}{c}\text { Average } \\
\text { Variance } \\
\text { Extracted }\end{array}$ & $\mathbf{1}$ & $\mathbf{2}$ & $\mathbf{3}$ & $\mathbf{4}$ & $\mathbf{5}$ & $\mathbf{6}$ & $\mathbf{7}$ \\
\hline $\begin{array}{l}\text { 1. Market } \\
\text { Orientation }\end{array}$ & 5.39 & 0.96 & 0.85 & 0.54 & 1.00 & & & & & \\
$\begin{array}{l}\text { 2. Innovation } \\
\text { Orientation }\end{array}$ & 3.36 & 0.85 & 0.89 & 0.67 & 0.41 & 1.00 & & & & \\
$\begin{array}{l}\text { 3. Inside-out } \\
\text { Capabilities }\end{array}$ & 3.45 & 0.64 & 0.75 & 0.42 & 0.34 & 0.52 & 1.00 & & & & \\
$\begin{array}{l}\text { 4. Outside-in } \\
\text { Capabilities }\end{array}$ & 3.87 & 0.74 & 0.79 & 0.66 & 0.29 & 0.35 & 0.47 & 1.00 & & \\
$\begin{array}{l}\text { 5. Competitive } \\
\text { Advantage }\end{array}$ & 3.24 & 1.03 & 0.75 & 0.60 & 0.24 & 0.41 & 0.21 & 0.22 & 1.00 & \\
$\begin{array}{l}\text { 6. Market } \\
\text { Performance }\end{array}$ & 3.37 & 0.88 & 0.75 & 0.60 & 0.10 & 0.31 & 0.37 & 0.20 & 0.18 & 1.00 & \\
$\begin{array}{l}\text { 7. Financial } \\
\text { Performance }\end{array}$ & 3.40 & 0.89 & 0.88 & 0.71 & 0.13 & 0.27 & 0.39 & 0.19 & 0.22 & 0.53 & 1.00 \\
\hline
\end{tabular}


Table 2. Results summary

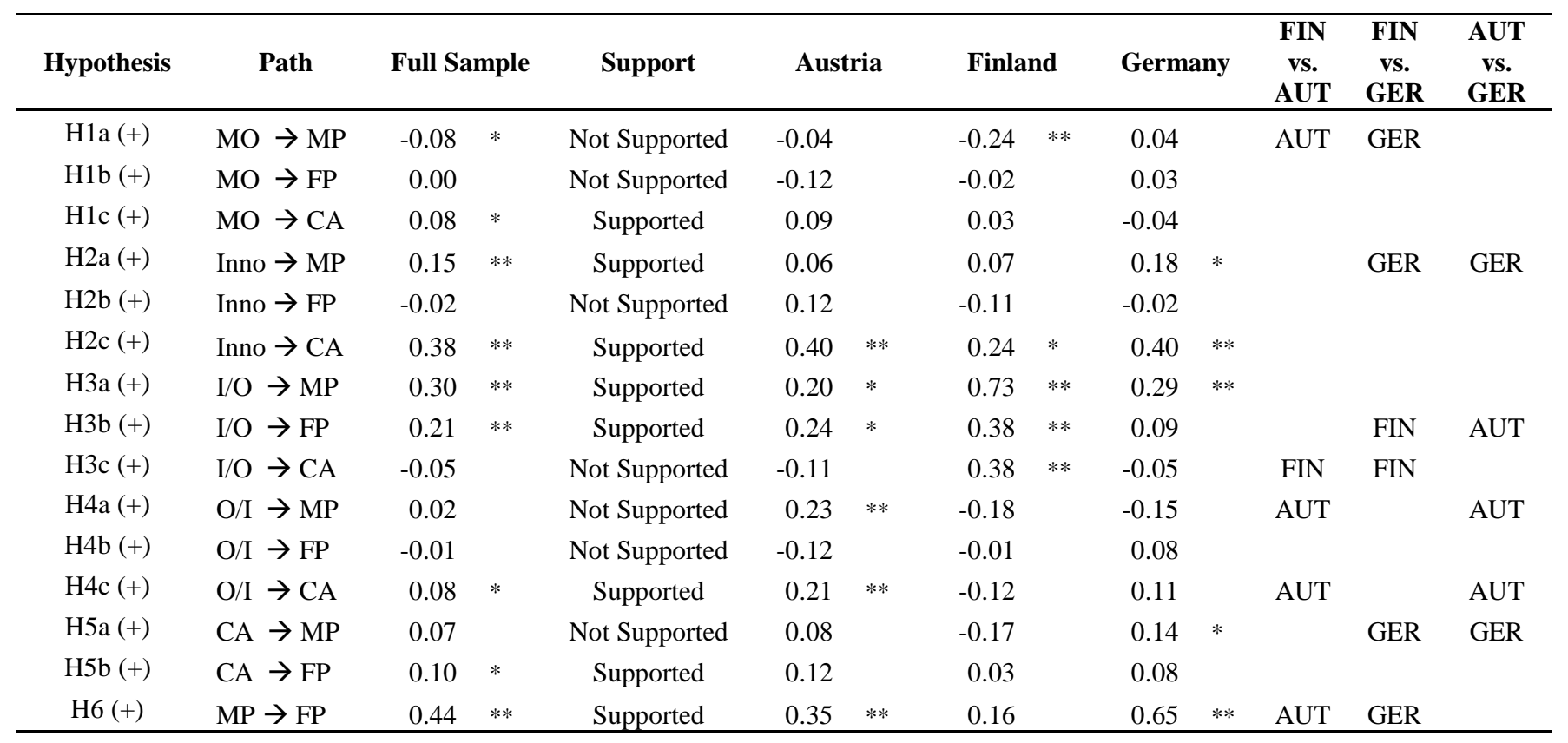

$* \mathrm{p}<0.05$ (two-tailed) $\quad \mathrm{MO}=$ Market Orientation, Inno $=$ Innovation Orientation, $\mathrm{I} / \mathrm{O}=$ Inside-out Capabilities, O/I = Outside-in Capabilities

** $\mathrm{p}<0.01$ (two-tailed) $\quad \mathrm{CA}=$ Competitive Advantage, $\mathrm{MP}=$ Market Performance, $\mathrm{FP}=$ Financial Performance 
Table 3. Total effects on financial performance in engineering countries

\begin{tabular}{lcccc}
\hline \multicolumn{1}{c}{ Construct } & All countries & Austria & Finland & Germany \\
\hline Market Orientation & -0.03 & -0.12 & -0.06 & 0.05 \\
Innovation Orientation & 0.10 & 0.20 & -0.09 & 0.16 \\
Inside-out Capabilities & 0.34 & 0.29 & 0.49 & 0.27 \\
Outside-in Capabilities & 0.01 & -0.01 & -0.04 & 0.01 \\
Total Effects Combined & $\mathbf{0 . 4 2}$ & $\mathbf{0 . 3 6}$ & $\mathbf{0 . 3 0}$ & $\mathbf{0 . 4 9}$ \\
\hline
\end{tabular}




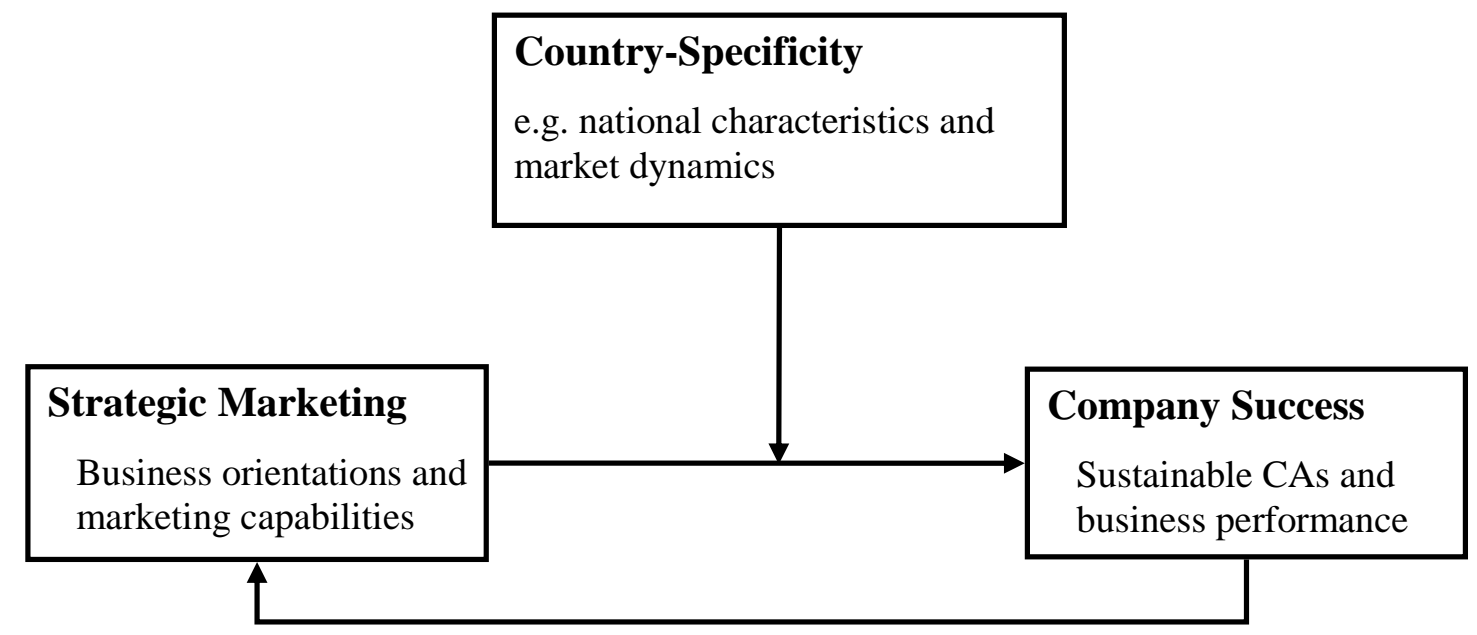

Figure 1. Study framework 


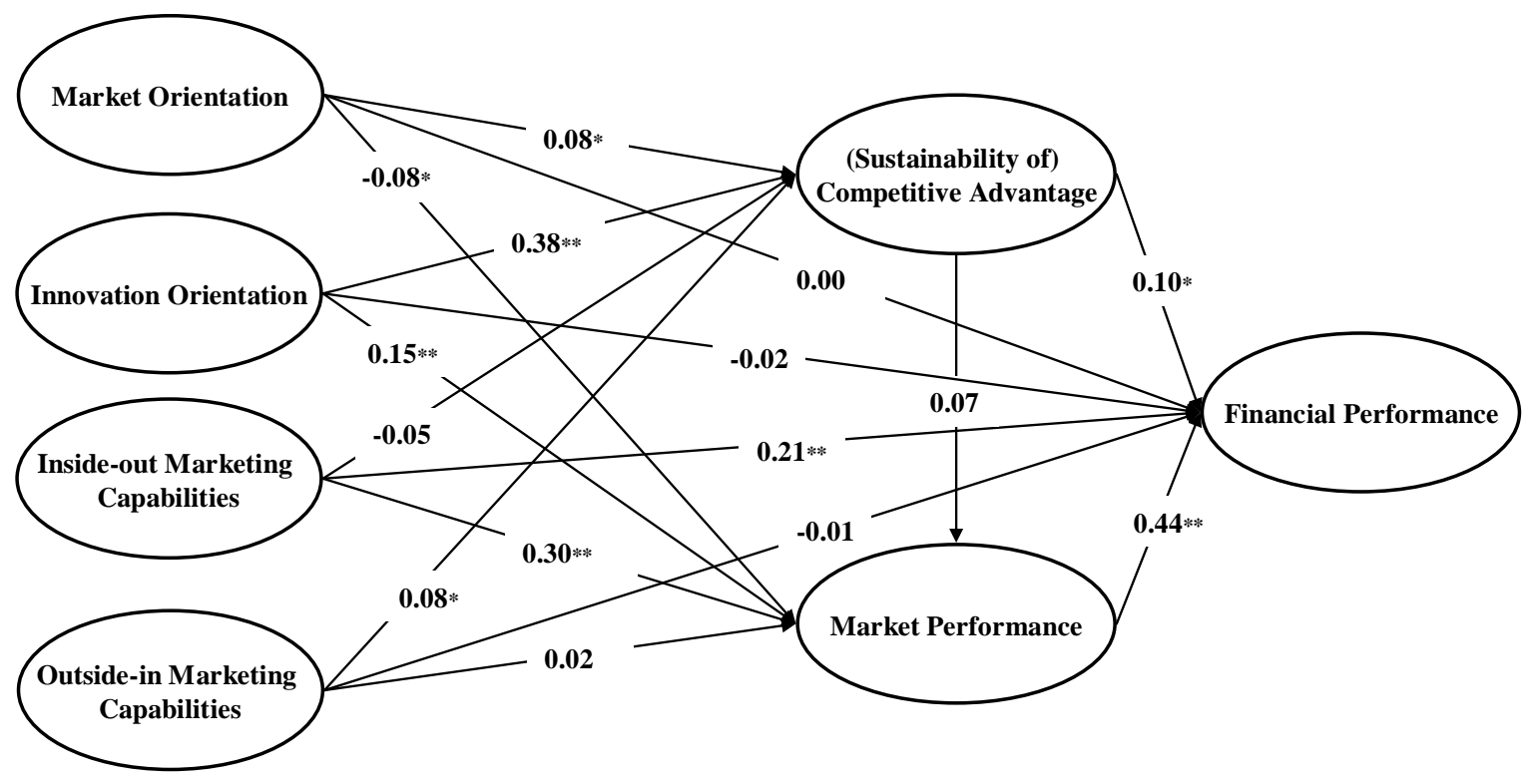

Figure 2. Structural model with standardized path estimates $(* \mathrm{p}<0.05 ; * * \mathrm{p}<0.01)$

Model Fit: $\chi^{2}(188)=604.72 ; p<0.0001$, RMSEA=0.048, CFI=0.98, NNFI=0.97 and GFI=0.95. 